\title{
A new primnoid genus (Anthozoa: Octocorallia) from the Southern Ocean*
}

\author{
PABLO J. LÓPEZ-GONZÁLEZ1 ${ }^{1}$, JOSEP-MARIA GILI² and COVADONGA OREJAS ${ }^{3}$ \\ ${ }^{1}$ Departamento de Fisiología y Zoología, Facultad de Biología, Universidad de Sevilla, Reina Mercedes 6, \\ 41012-Sevilla, Spain. E-mail: pjlopez@us.es. \\ ${ }_{2}^{2}$ Institut de Ciències del Mar, CMIMA-CSIC, Passeig Marítim de la Barceloneta, 37-49, 08003 Barcelona, Spain. \\ ${ }^{3}$ Alfred-Wegener-Institut für Polar und Meeresforschung, Columbusstrasse, 27568, Bremerhaven, Germany.
}

\begin{abstract}
SUMMARY: A new primnoid genus is here proposed based on the study of the type material of Primnoella gracilis Molander, 1929 and the abundant material collected during some recent Antarctic and Subantarctic cruises. The new genus, Arntzia, is compared with its closest primnoid genera, mainly Ainigmaptilon Dean and Primnoella Gray. Arntzia differs from other unbranched primnoids by a set of features such as its colonies of fleshy consistence, relatively low spicule density, polyps in whorls, fused basally, forming a common brood-chamber along the axial coenenchyme where oocytes develop, eight distalmost opercular scales larger than marginal or submarginal scales, two adaxial opercular scales smaller than the others, marginal scales in equal number to opercular, vertically aligned with opercular scales, not well-differentiated from the body scales below, and polyp body completely covered by scales, except for the proximal portion and basal part of the adaxial side. With the description of Arntzia, a total of 17 primnoid genera have been reported from the Southern Ocean (Antarctic and Subantarctic waters); moreover, 15 of them $-50 \%$ of the total in the familyhave been recorded exclusively in this area. Thus, the generic diversity of this family in the Southern Ocean should be considered remarkably high.
\end{abstract}

Key words: Southern Ocean, Antarctica, biodiversity, new genus, Arntzia.

RESUMEN: Un NUEVo GÉNERo DE PRIMNOIDEO (ANTHOZOA: OctocorALLIA) DEL OCÉANO ANTÁRTICO. - En este trabajo se describe un nuevo género de primnoideos (gorgonia) en base a un estudio del material tipo de Primnoella gracilis Molander, 1929 y a numeroso material recolectado durante expediciones antárticas recientes. El nuevo género, Arntzia, se compara con los géneros Ainigmaptilon Dean y Primnoella Gray, los más próximos de la familia Primnoidae. Arntzia se diferencia de estos géneros de colonias no ramificadas por un conjunto de caracteres como la consistencia carnosa de las colonias, por su relativa baja densidad de espículas, por tener los pólipos organizados en círculos y fusionados en la base, y forman una cámara incubadora común a lo largo del cenénquima, por tener ocho placas distales del opérculo más largas de las marginales o submarginales, por tener dos placas operculares adaxiales más pequeñas que las otras, y por un número igual de placas marginales que operculares alineadas juntas y dificilmente distinguibles de las placas del cuerpo además de que el cuerpo de los pólipos está completamente cubierto por placas espiculares a excepción de la parte basal del lado adaxial. La descripción del género Arntzia incrementa a 17 el número de géneros de la familia Primnoidae encontrados en el Océano Antártico y 15 de ellos (50\% de los de la familia) se han encontrado tan sólo en aguas antárticas y subantárticas lo que hace que la diversidad de la familia en aguas antárticas sea muy elevada.

Palabras clave: Océano Antártico, biodiversidad, género nuevo Arntzia. 


\section{INTRODUCTION}

Recent work on biodiversity in Antarctic ecosystems has revealed that benthic communities in the Southern Ocean harbour a wealth of species much greater than could have been suspected a few decades ago (Arntz et al., 1994, 1997). As a result, the well-known latitudinal species-diversity gradient according to which the polar regions have lower levels of species diversity than the tropical region (Sanders, 1968), does not hold true for many groups (Clarke and Crame, 1989). The substantial increase in the number of research surveys carried out in Antarctic waters in recent years, with attention focusing on a large number of taxonomic groups (Arntz, 1997), has shown Antarctic benthic communities to be one of the most attractive marine regions for biodiversity studies.

The Antarctic benthos is not only rich in terms of species (Clarke and Crame, 1992), biomass values are also quite high, comparable to temperate and tropical ecosystems, though distribution tends to be much patchier (Brey and Clarke, 1993). The shelves and littoral zones below the level of icescour are dominated by dense communities of suspension feeders. Octocorals are one of the major components of these communities in terms of both abundance and diversity (Starmans et al. 1999). However, many Antarctic species belonging to this group are as yet unknown, present knowledge being estimated to encompass no more than $50 \%$ (Winston, 1992).

A wealth of octocoral specimens were collected on the three Polarstern cruises (ANT XIII/3, ANT $\mathrm{XV} / 3$, and ANT XVII/3) carried out in the eastern Weddell Sea and Antarctic Peninsula in the Austral summers of 1996, 1998, and autumn of 2000, respectively. In addition, two other Polarstern cruises (ANT XIX/3 and ANT XIX/4) prospected the Scotia Arc in the Austral summer of 2002. These cruises were carried out in the frame of the EASIZ (Ecology of Antarctic Sea Ice Zone) and ANDEEP (Antarctic Benthic Deep-Sea Biodiversity) programmes, respectively; both were carried out under the auspices of SCAR (Scientific Committee for Antarctic Research). Some of the species collected were quite abundant in the samples and in the videotape recordings made during the cruises (Gili et al., 1999). Most of these species belonged to the family Primnoidae, one of the most highly diverse families of octocorals in the Southern Ocean, with about 30 known genera (Bayer, 1980,
1981, 1988, 1996a, 1996b, 1998; Bayer and Stefani, 1988). Despite our present extensive knowledge of the diversity of this family, studies conducted on these previously mentioned cruises revealed that one of the most abundant species was Primnoella gracilis Molander, 1929. A detailed study of the anatomy of this species showed that it could not be placed in any of the previously described primnoid genera as suspected by Bayer (1996a: 179). The present paper describes this new genus and compares it with other primnoid genera, mainly Ainigmaptilon Dean and Primnoella Gray. The description of the new genus is based on the study of the type material of $P$. gracilis deposited in the Swedish Museum of Natural History (Stockholm) and the abundant material collected during the Polarstern EASIZ and ANDEEP cruises, some Italian collections and a colony collected under the United States Antarctic Research Programme (USARP).

\section{MATERIALS AND METHODS}

Colonies from EASIZ and ANDEEP cruises were collected with the aid of different gears (TV grab, Agassiz trawl, bottom trawl). Octocorals were sorted, labelled and fixed on board in $4 \%$ buffered formalin in sea water, and subsequently preserved in $70 \%$ ethanol. Fragments of colonies, whole polyps, and sclerites from different parts of the colonies were prepared for study by SEM following the methods of Bayer and Stefani (1988), and permanent mounts were made for observation under light microscopy. For histological studies selected portions of the colony including polyps were decalcified in formic acid 10\%, dehydrated in butanol (Johansen, 1940), and embedded in paraffin wax. Histological sections 6-10 $\mu$ m thick were mounted, and stained with Ramón y Cajal's Triple Stain (Gabe, 1968).

The material of the species described in this paper is deposited in the Swedish Museum of Natural History (SMNH) in Stockholm, the Zoologisches Museum Hamburg (ZMH), the National Museum of Natural History, Smithsonian Institution (USNM) in Washington, the Natural History Museum (NHM) in London, the Instituto de Ciencias del Mar (ICM) in Barcelona, the Section of Zoology (SZ) of the Faculty of Biology at the University of Seville, and the Museo de la Universidad Nacional de la Plata (MUNP) in La Plata, Buenos Aires. 
SYSTEMATIC ACCOUNT

\section{Family PRIMNOIDAE}

Arntzia gen. nov.

Primnoella Molander, 1929: 63 (part); Bayer, 1996: 179 (part in text)

Diagnosis: Flagelliform, unbranched Primnoidae. Colonies not densely spiculated, (more densely spiculated in young specimens, becoming of fleshy consistence in larger ones). Polyps tall, cylindrical, standing almost vertical from the axis but fleshy and flexible, arranged in whorls. Bases of polyps fused basally. Basal brooding part of the polyps fused forming a common brood-chamber within the axial coenenchyme. Eight distalmost opercular scales, larger than marginal or submarginal scales. Two adaxial opercular scales smaller than the others. Marginal scales in equal number to opercular, vertically aligned with opercular scales, not well differentiated from the body scales below. Body completely covered by scales, except for the proximal portion and basal part of the adaxial side of polyps. Coenenchymal sclerites scale-like, with a deeper layer of small, tuberculate sclerites.

Type species: Primnoella gracilis Molander 1929, here designated.

Etymology: The name Arntzia is chosen in honour of Prof. Dr. Wolf E. Arntz (Alfred Wegener Institut für Polar und Meeresforschung, Bremerhaven), in recognition of his valuable contributions to the knowledge of polar ecosystems. The gender is feminine.

Arntzia gracilis (Molander, 1929) comb. nov. (Figs. 1-7)

Primnoella gracilis Molander 1929:63, figs. 17, 18; pl. 1, fig. 2; Bayer 1996:179 (in text).

Material examined: Holotype: SMNH-Type-1140 of Primnoella gracilis Molander, 1929, Swedish South Polar Expedition 190103, stn. 22, South Georgia, Cumberland Bay, off May Bay, $54^{\circ} 17^{\prime} \mathrm{S} 36^{\circ} 28^{\prime} \mathrm{W}, 75 \mathrm{~m}, 14$ May 1902 , one whole colony with holdfast attached to stone, $305 \mathrm{~mm}$ in length; SZ (ANT-1763), R/V Polarstern, cruise ANT V/4, stn. 672, 76 $36.6^{\prime} \mathrm{S} 30^{\circ} 34.1^{\prime} \mathrm{W}$, $264 \mathrm{~m}, 12$ Jan 87, one colony without holdfast; ZMH (C 11677), R/V Polarstern, cruise ANT XV/3, stn. 48/035, 7107.2'S $11^{\circ} 28.2^{\prime} \mathrm{W}, 64 \mathrm{~m}, 29 \mathrm{Jan} 1998$, one colony complete with holdfast attached to stone; ZMH (C 11678), R/V Polarstern, cruise ANT

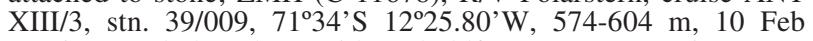
1996, one whole colony without holdfast; ZMH (C 11679), R/V Polarstern, cruise ANT XV/3, stn. 48/210, 71 ${ }^{\circ} 7.2^{\prime}$ 'S $11^{\circ} 28.4^{\prime} \mathrm{W}$, $67 \mathrm{~m}, 18 \mathrm{Feb} 1998$, one whole colony without holdfast; ZMH (ANT-1766), Polarstern R/V, cruise ANT XV/3, stn. 48/210,

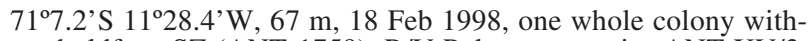
out holdfast; SZ (ANT-1759), R/V Polarstern, cruise ANT XV/3, stn. 48/036, 71 $7.2^{\prime}$ 'S $11^{\circ} 28.2^{\prime} \mathrm{W}, 68 \mathrm{~m}, 29 \mathrm{Jan} 1998$, one whole colony without holdfast; NHM (2002.686), R/V Polarstern, cruise ANT XV/3, stn. 48/194, 71 ${ }^{\circ} 14.1^{\prime} \mathrm{S} 12^{\circ} 27.7^{\prime} \mathrm{W}, 244-246 \mathrm{~m}, 16 \mathrm{Feb}$ 1998, one whole colony; SZ (ANT-1762), Polarstern R/V, cruise ANT XV/3, stn. 48/220, 70 54.4'S 10 35.4'W, 236-272 m, 19 Feb 1998, tow colonies without holdfast; MLP (8518), R/V Polarstern, cruise ANT XV/3, stn. 48/353, 61 ${ }^{\circ} 59.4^{\prime}$ 'S 59 $9^{\circ} 14.4^{\prime} \mathrm{W}, 129-1321$ m, 20 Mar 98, one colony without holdfast; SZ (ANT-1757), R/V Polarstern, cruise ANT XV/3, stn. 48/050, 70 $51.6^{\prime}$ 'S 10 $24.3^{\prime} \mathrm{W}$, 282-283 m, 30 Jan 1998, one colony without holdfast; SZ (ANT1760), R/V Polarstern, cruise ANT XVII/3, stn. 56/119.1, $70^{\circ} 50.40^{\prime} \mathrm{S} 10^{\circ} 35.20^{\prime} \mathrm{W}, 226-266 \mathrm{~m}, 7$ Apr 2000 , one colony without holdfast; SZ (ANT-1758), R/V Polarstern, cruise ANT XVII/3, stn. 56/124, 7050.6'S $10^{\circ} 35.40^{\prime} \mathrm{W}, 247-269$ m., 9 Apr 2000, one colony without holdfast; SZ (ANT-1761), R/V Polarstern, cruise ANT XVII/3, stn. 56/110.6, 71 ${ }^{\circ} 18.10^{\prime}$ S $12^{\circ} 15.95^{\prime} \mathrm{W}, 179 \mathrm{~m}, 4$ Apr 2000 , one colony without holdfast; MLP (8520), R/V Polarstern, cruise ANT XVII/3, stn. 56/135.1, $70^{\circ} 50.20^{\prime} \mathrm{S} 10^{\circ} 34.70^{\prime} \mathrm{W}, 273-274 \mathrm{~m}, 10 \mathrm{Apr} 2000$, one whole colony; NHM (2002.687-689), R/V Polarstern, cruise ANT XVII/3, stn. 56/135.1, 7050.20'S $10^{\circ} 34.70^{\prime} \mathrm{W}, 273-274 \mathrm{~m}, 10$ Apr 2000, three whole colonies; SZ (ANT-1768), Terra Nova Bay, Z 200, 74²42.20’S 16408.50'E, 200 m, 2 Jan 1990, one colony fragmented; SZ (ANT-1771), Terra Nova Bay, MM 94, 74³9.07'S 164'9.93'E, 300 m, 27 Jan 1990, one whole colony; SZ (ANT-1770), Terra Nova Bay, C 160, 74²6.51'S 164³.70'E, $160 \mathrm{~m}, 7$ Jan 1990, one colony fragmented into 3 parts; SZ (ANT1767), Terra Nova Bay, E $2 \mathrm{D}$, coordinates not recorded, $100 \mathrm{~m}$, 24 Dec 1989, one large colony fragmented; SZ (ANT-1764), Terra Nova Bay, E 2 D, coordinates not recorded, 100 m, 24 Dec 1989, 9 colonies fragmented; SZ (ANT-1765), Terra Nova Bay, E 2 D, coordinates not recorded, $100 \mathrm{~m}, 24$ Dec 1989, 8 colonies fragmented; SZ (ANT-1769), Terra Nova Bay, VARB-5, 7442.51'S $164^{\circ} 9.74^{\prime} \mathrm{E}, 260 \mathrm{~m}, 31$ Jan 1994, 2 whole colonies; SZ (ANT1755), R/V Polarstern, cruise ANT XIX/3, stn. 61/058.1, $60^{\circ} 59.76$ ' S 55 43.16'W, 106-113 m, 1 Feb 2002, one colony without axis and holdfast; SZ (ANT-1751), R/V Polarstern, cruise

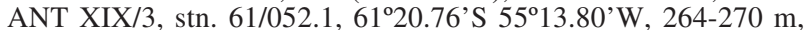
31 Jan 2002, two colonies without axis and holdfast; SZ (ANT1752), R/V Polarstern, cruise ANT XIX/3, stn. 61/053.1, $61^{\circ} 20.51^{\prime} \mathrm{S} 55^{\circ} 28.66^{\prime} \mathrm{W}, 117-159 \mathrm{~m}, 31 \mathrm{Jan} 2002$, one colony without axis and holdfast; SZ (ANT-1749), R/V Polarstern, cruise ANT XIX/3, stn. 61/054.1, 61 ${ }^{\circ} 15.50$ 'S 55 $36.99^{\prime} \mathrm{W}, 90.8-110.4$ $\mathrm{m}, 1 \mathrm{Feb} 2002$, one colony without axis and holdfast; SZ (ANT1717), R/V Polarstern, cruise ANT XIX/3, stn. 61-101.1, 61 ${ }^{\circ} 48.62^{\prime} \mathrm{S} 58^{\circ} 38.30^{\prime} \mathrm{W}, 390-490 \mathrm{~m}, 13 \mathrm{Feb} 2002$, five fragments without axis; SZ (ANT-1544), R/V Polarstern, cruise ANT XIX/3, stn 102, 61 $46.94^{\prime} \mathrm{S} 58^{\circ} 38.66^{\prime} \mathrm{W}, 277-281 \mathrm{~m}, 13$ Feb 2002, one colony without holdfast; SZ (ANT-1753), R/V Polarstern, cruise

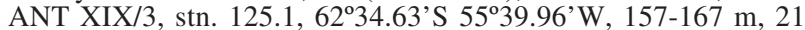
Feb 2002, two colonies without holdfast, one of them without axis; USNM 97989, USARP, cruise 824, Hero R/V, stn. 25-2, $64^{\circ}$ $20.90^{\prime} \mathrm{S} 61^{\circ} 35.50$ 'W, $92 \mathrm{~m}$, 24 Mar 1982, one whole colony; USNM 58251, USARP, Deep Freeze cruise, Edisto R/V, stn. 8, $77^{\circ} 26^{\prime} \mathrm{S} 169^{\circ} 30^{\prime} \mathrm{E}, 321 \mathrm{~m}, 18$ Feb 1956, one whole colony without holdfast; USNM 58252, USARP, cruise 66, Eastwind R/V, stn. 8, 63 33.24S $60^{\circ} 15.24$ 'W, 96.9-113.4 m, 31 Jan 1966, one whole colony without holdfast; USNM 58253, USARP, cruise 66,

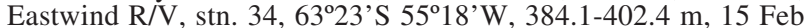
1966, 23 colonies, some of them with holdfast; USNM 58254, USARP, collector W. Schmitt, stn. 27-63, 64\% $43.20 \mathrm{~S} 63^{\circ} 36^{\prime} \mathrm{W}, 75$ m, 5 Feb 1963, one colony without holdfast; USNM 58255, US Navy Antarctic Expedition, collector D.C. Nutt, stn. 190, Marguerite Bay, $64 \mathrm{~m}, 20 \mathrm{Feb} 1948$, one fragmented colony without holdfast; USNM 78666, USARP, cruise 876, Islas Orcadas R/V, stn. $109,60^{\circ} 26^{\prime} \mathrm{S} 46^{\circ} 28^{\prime} \mathrm{W}, 106-115 \mathrm{~m}, 16 \mathrm{Feb} 1976$, three colonies without holdfast; USNM 79613, USARP, cruise 721 , Hero R/V, stn. 850, 64²47.18'S 64'06.42'W, 165 m, 26 Jan 1972. 4 colonies, one of them with holdfast; USNM 82097, USARP, cruise 12, Eltanin R/V, stn. 1002, 62 $42^{\circ}$ 'S $54^{\circ} 45^{\prime} \mathrm{W}, 265 \mathrm{~m}, 15$ Mar 1964, 2 colonies, one of them with holdfast; USNM 82870 , USARP, cruise 824 , Hero R/V, stn. 41-1, 64\% $48^{\prime}$ 'S $64^{\circ} 07^{\prime} \mathrm{W}, 88^{-}$ 112 m, 29 Mar 1982, one colony with holdfast; USNM 98238, USARP, cruise 876, Islas Orcadas R/V, stn. 107, 60 26.30'S $46^{\circ} 22.48^{\prime} \mathrm{W}, 102-108 \mathrm{~m}, 16 \mathrm{Feb} 1976$, eleven young colonies, some of them still attached to small stones. 

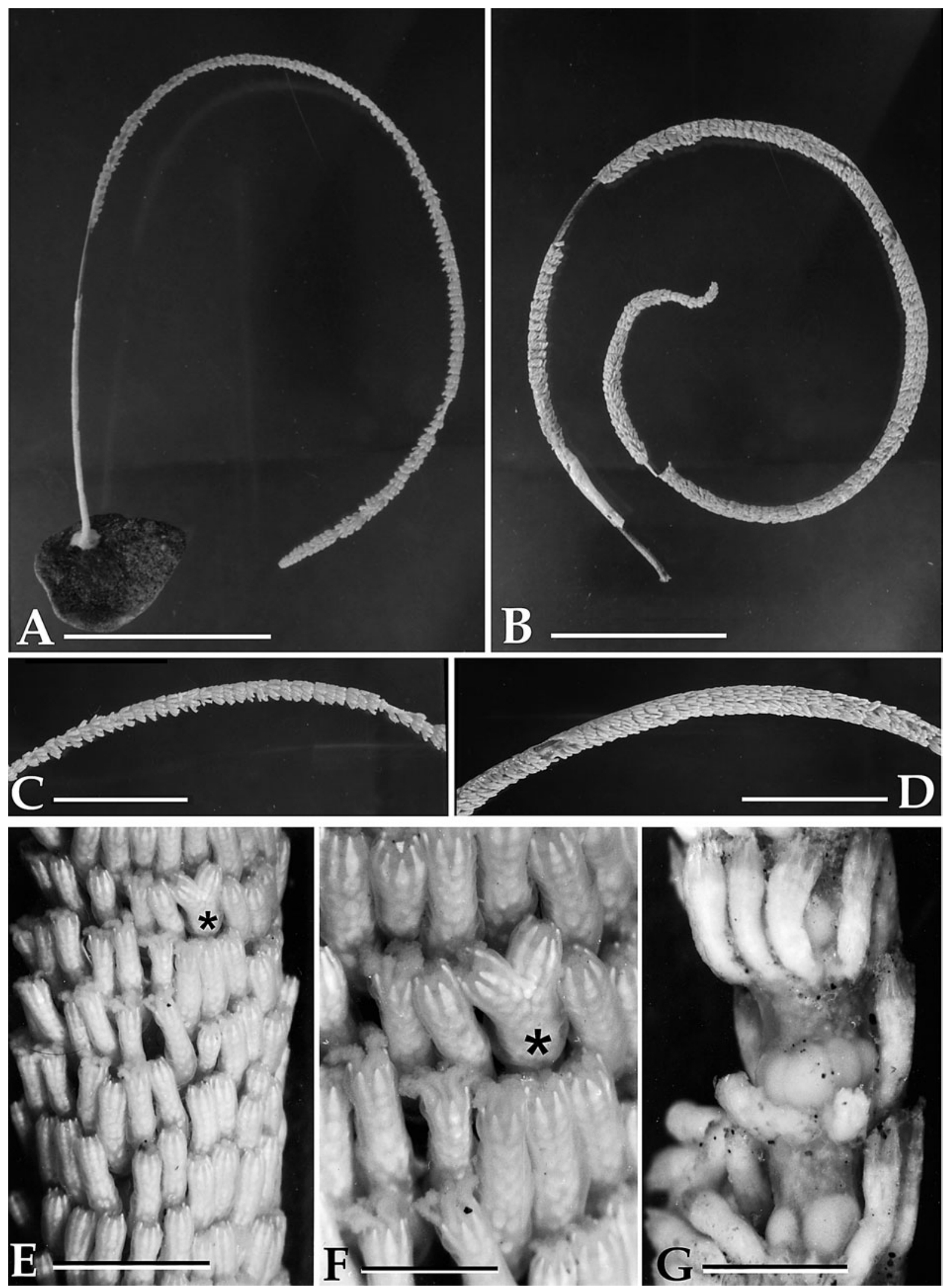

FIG. 1. - Arntzia gracilis (Molander, 1929) comb. nov.: A, holotype colony, SMNH-Type-1140; B colony from EASIZ-II cruise; C and D, detail from A and B, respectively; $\mathbf{E}$ and $\mathbf{F}$, details from a large colony, with nearly 20 polyps per whorl, note the presence of "twin polyps" (asterisk); G, detail of a colony, note the brooding stage of the polyps with developing oocytes forming part of the axis. Scale bars: A and B, $50 \mathrm{~mm} ; \mathrm{C}$ and D, $25 \mathrm{~mm}$, E, $6 \mathrm{~mm} ; \mathrm{F}, 1.5 \mathrm{~mm} ; \mathrm{G}, 3 \mathrm{~mm}$. 
Diagnosis: As for the genus.

Description: Colony flagelliform, whip-like, medium-size and larger colonies of fleshy consistence (young colonies could be more densely spiculated), and noticeably flexible, up to $1150 \mathrm{~mm}$ long and about 4(5.5) $\mathrm{mm}$ in maximum diameter, arising from a discoidal, spreading holdfast devoid of polyps (Fig. 1).

Polyps cylindrical, about $2.5-4 \mathrm{~mm}$ tall and approximately $0.6-1 \mathrm{~mm}$ in diameter, set in whorls of 12-22 on low annular thickenings of coenenchyme, with proximal portion partially or negligibly fused, notable mainly in reproductive stages. Polyps directed upwards, but not strongly adhered to the coenenchyme. About 3-6 whorls per $\mathrm{cm}$ of axial length. Polyps with eight longitudinal rows of scales perfectly aligned on the distal half of the polyp, sometimes an irregular arrangement or complete absence of scales on the proximal half. Scales slightly overlapping (depending on contraction state) (Fig. 2).

Distalmost scales more or less triangular and pointed (Figs. 2D,2F,3,5), 0.51-0.80 x 0.15-0.25 $\mathrm{mm}$, the two adaxial scales smaller 0.35-0.50 x 0.09$0.15 \mathrm{~mm}$. Marginal scales also smaller, more or less rounded or polygonal, similar to the remaining body scales (Figs. 2B-D, 2F). Abaxial and lateral longitudinal rows with 8-11 scales (Fig. 2B, 2E, 3, 5), 0.26$0.37 \times 0.18-0.26 \mathrm{~mm}$, the two adaxial longitudinal rows with 4-5(6) scales smaller in size, 0.15-0.21 x $0.13-0.16 \mathrm{~mm}$, than the abaxial and marginal scales. Basal portion of polyps and proximal on adaxial side of body naked and markedly fleshy (mainly in medium-size and large colonies).

Coenenchyme thick, about $0.4 \mathrm{~mm}$, with an outer layer containing sclerites like those on the bodies of polyps (Figs. 4A, 6A), 0.11-0.32 mm. The inner layer, containing the longitudinal stem canals, with more or less irregular rods covered by compound tubercles (Figs. 4A-6A), 0.09-0.19 mm, some of the sclerites appearing to be the nucleus of other scales. Superficial coenenchymal scale-like and inner irregular sclerites, more densely packed in smaller colonies than in larger ones. Proximal portion of colony devoid of polyps, with discoidal, elongate, more or less irregular sclerites (Figs. 4B-6B), 0.08$0.31 \mathrm{~mm}$, covered by compound tubercles.

Basal portion of coelenteric cavities poorly differentiated individually running upward along the axial coenenchyme (Fig. 7B), forming finally a common brood-chamber per whorl where large oocytes develop (Fig. 7). Coenenchyme between consecutive whorls cavernous due to abundant solenia (Fig. 2A). Internal ring of longitudinal canals well developed (Fig. 7D). Each channel more or less triangular in section with large lumen and thin intercanal walls. Axis flexible, up to $4 \mathrm{~mm}$ in diameter at the proximal portion, cross section of undulate outline (Fig. 7E).

Geographical and depth distribution: At present, Arntzia gracilis is known from Antarctic and Subantarctic zones from the Weddell Sea, Scotia Arc and Ross Sea, thus, a circumpolar distribution in the Southern Ocean is possible according to the current available data. The bathymetric distribution of $A$. gracilis varies between 64 and $604 \mathrm{~m}$.

\section{DISCUSSION}

Some remarks on the division in subfamilies of the family Primnoidae: Wright and Studer (1889: 47) distinguished four subgroups, namely Callozostroninae, Calytrophorinae, Primnoinae and Primnoidinae. Versluys (1906) restructured the family into five subfamilies, namely Callozostroninae, Primnoidinae, Primnoinae, Primnoellinae and Thouarellinae. However, Versluys' subfamilies were not accepted and Wright and Studer's original subfamilies were followed by subsequent authors (see Kükenthal, 1924; Bayer, 1981; Brito, 1993). In 1926, Isobe Dean described one of the most bizarre gorgonacean genera, Ainigmaptilon. Several controversies about the appropriate placement of this genus have been discussed since its original description. Molander (1929) created the subfamily Lycurinae within the Primnoidae for his genus Lycurus, a junior synonym of Ainigmaptilon. Firstly, Carlgren (1943) and later Bayer (1950) recognized the necessity of including Ainigmaptilon in a different family, Ainigmaptilidae. The formation of distinct polyp-leaves was the principal feature that led these authors to propose the Ainigmaptilidae as a family different from the Primnoidae. However, the presence of typical primnoid scale-like sclerites was a major inconvenience. Thus, in the most recent reports, this genus has been considered within the Primnoidae (Bayer, 1981:946; Bayer and Stefani, 1988: 455). Actually, the unique features displayed by the species of the genus Ainigmaptilon induce us to consider it included in a valid subfamily, Ainigmaptilinae, within the 

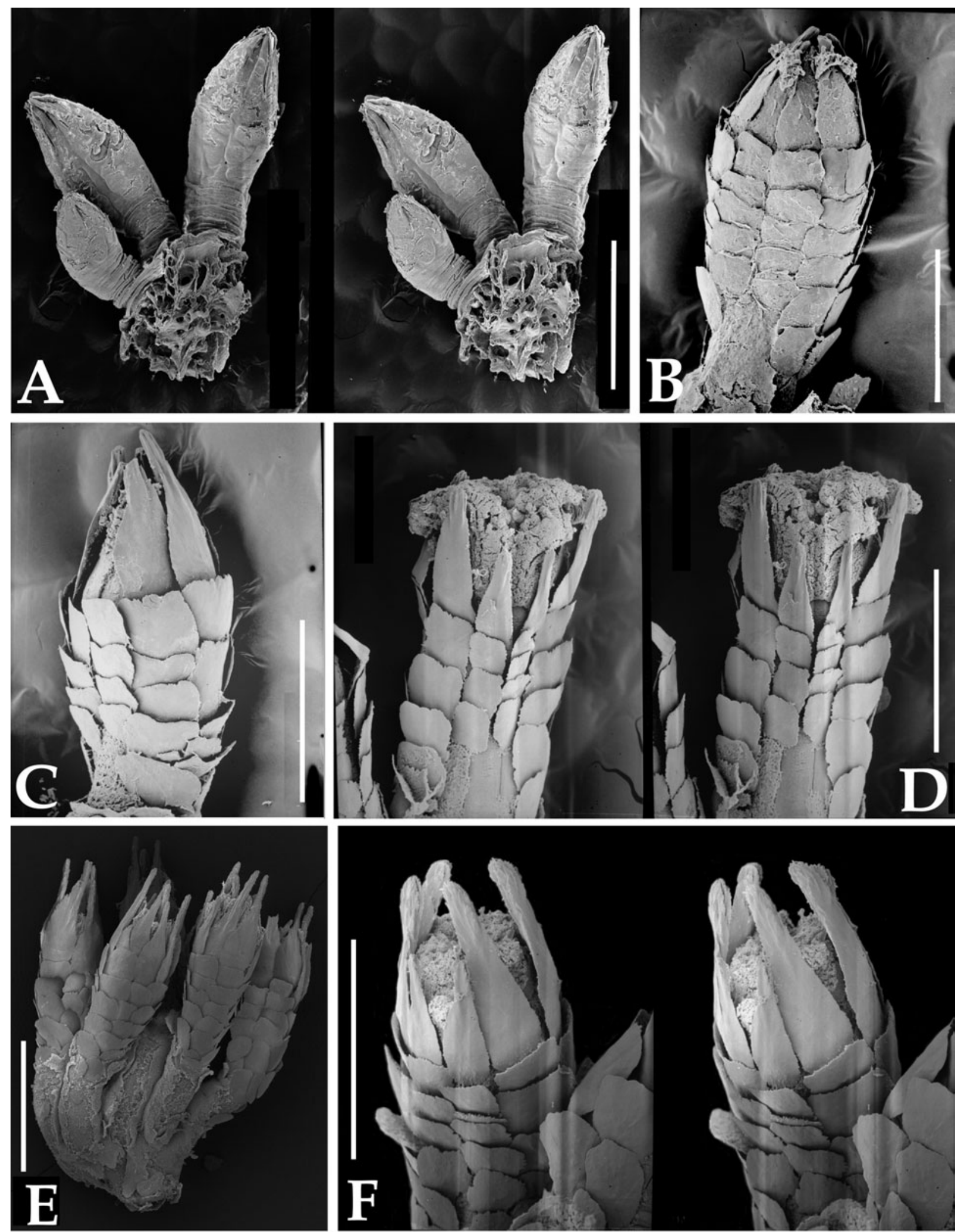

FIG. 2. - Arntzia gracilis (Molander, 1929) comb. nov. A, three polyps from the holotype colony, epidermis has not been removed, note the fleshy consistence of the basal part of the polyps and the cavernous common coenenchyme, stereo pair; $\mathbf{B}$, adaxial distal portion of a polyp from the holotype, epidermis has been partially removed in order to show the adaxial scales in natural position, note the difference in size respect to the lateral scales; $\mathbf{C}$, adaxial-lateral distal portion of a polyp from the holotype; $\mathbf{D}$, adaxial distal portion of a polyp, note the difference in size of the two adaxial row of sclerites compared to lateral ones, stereo pair; $\mathbf{E}$, group of polyps, abaxial side; $\mathbf{F}$, polyp in lateral view, stereo pair. Scale bars: A, $1 \mathrm{~mm}$; B - D, $0.6 \mathrm{~mm}$; E, $0.4 \mathrm{~mm}$; F, $0.6 \mathrm{~mm}$. 


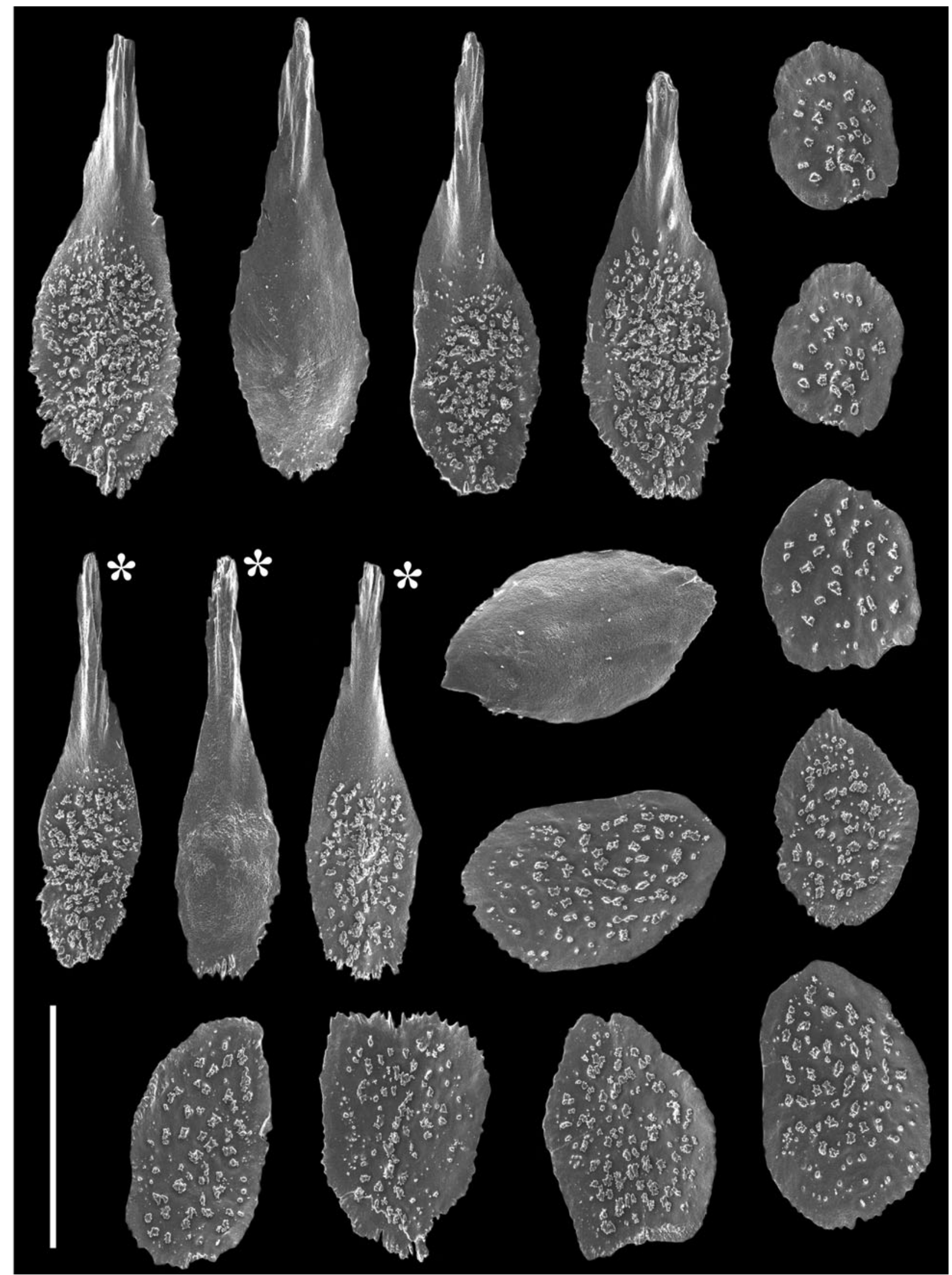

FIG. 3. - Arntzia gracilis (Molander, 1929) comb. nov. Holotype: Sclerites from the polyps, note the difference in size between the adaxial distalmost scales (asterisks) on the second row and the lateral and adaxial distalmost scales on the first row. Scale bar: $0.3 \mathrm{~mm}$. 


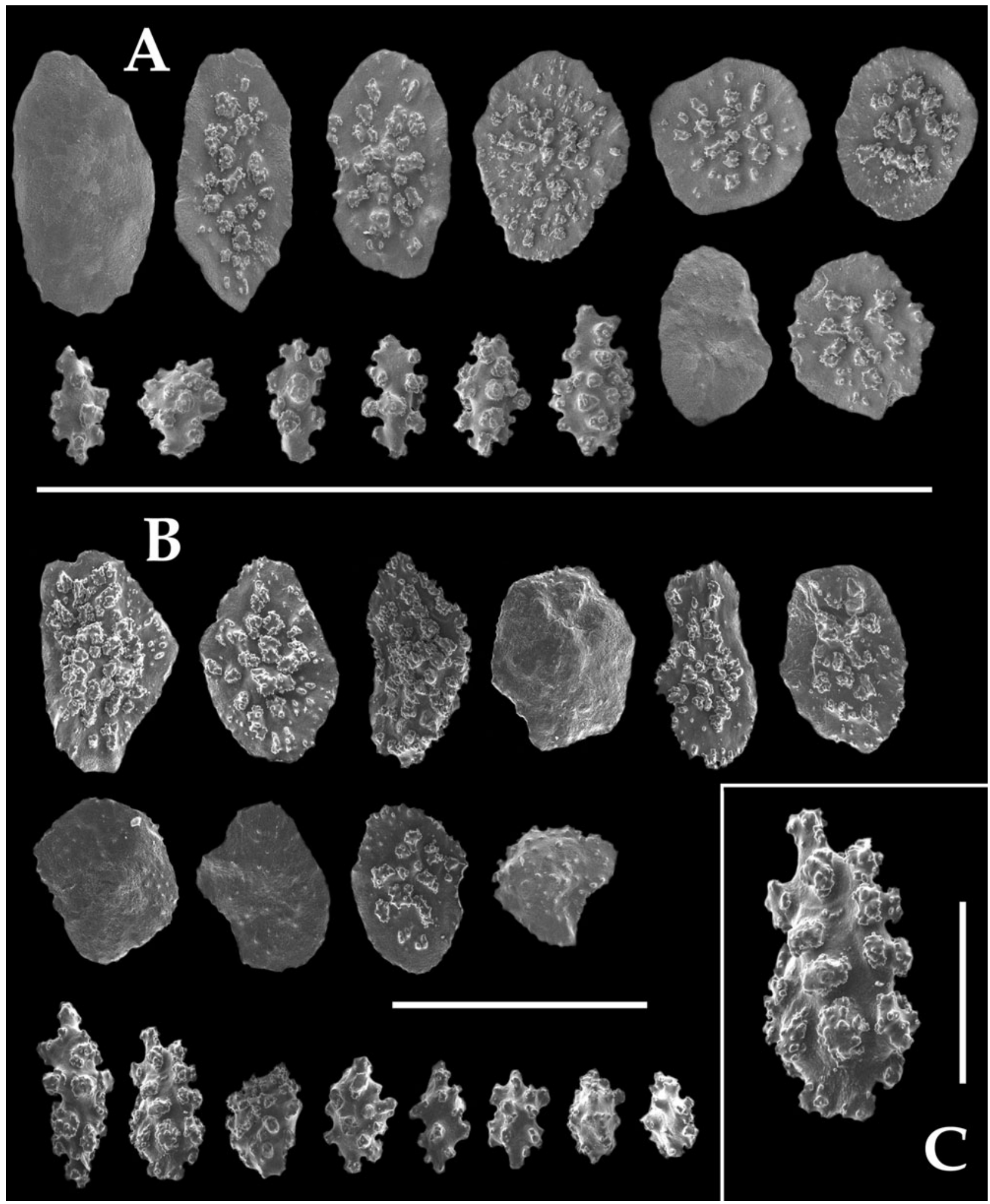

FIG. 4. - Arntzia gracilis (Molander, 1929) comb. nov. Holotype: A, sclerites from the coenechyme between polyps whorls; B, sclerites from the coenechyme at the basal polyp-free portion of the colony; C, one of the irregular sclerites of B enlarged. Scale bars: A and B, $0.3 \mathrm{~mm}$, C, $0.1 \mathrm{~mm}$.

FIG. 5. - Arntzia gracilis (Molander, 1929) comb. nov., colony from EASIZ-II cruise: Sclerites from the polyps, note the difference in size between the adaxial distalmost scales (asterisks) on the second row and the lateral and adaxial distalmost scales on the first row. Scale bar: $0.3 \mathrm{~mm}$ 


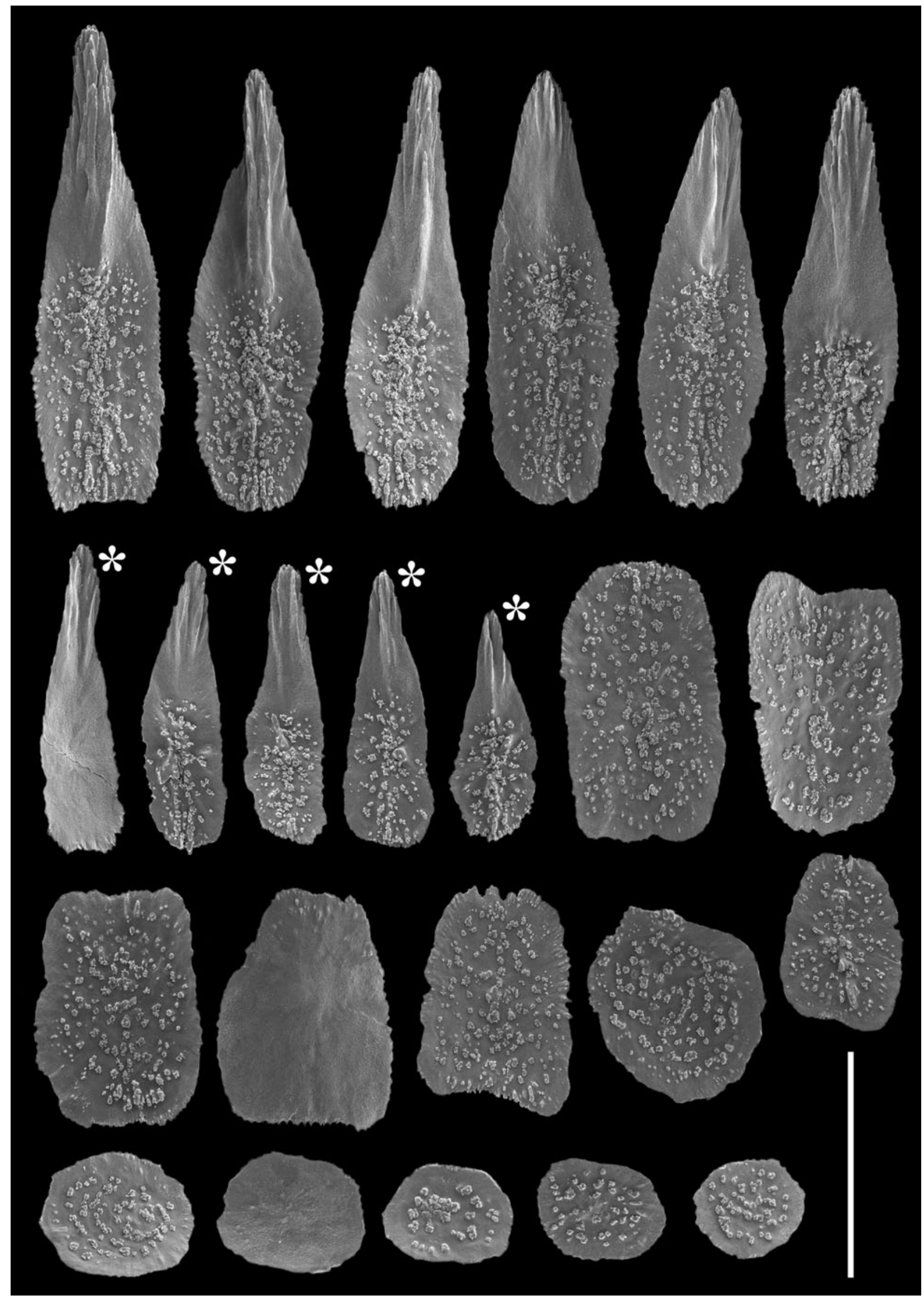

A NEW ANTARCTIC PRIMNOID GENUS 391 

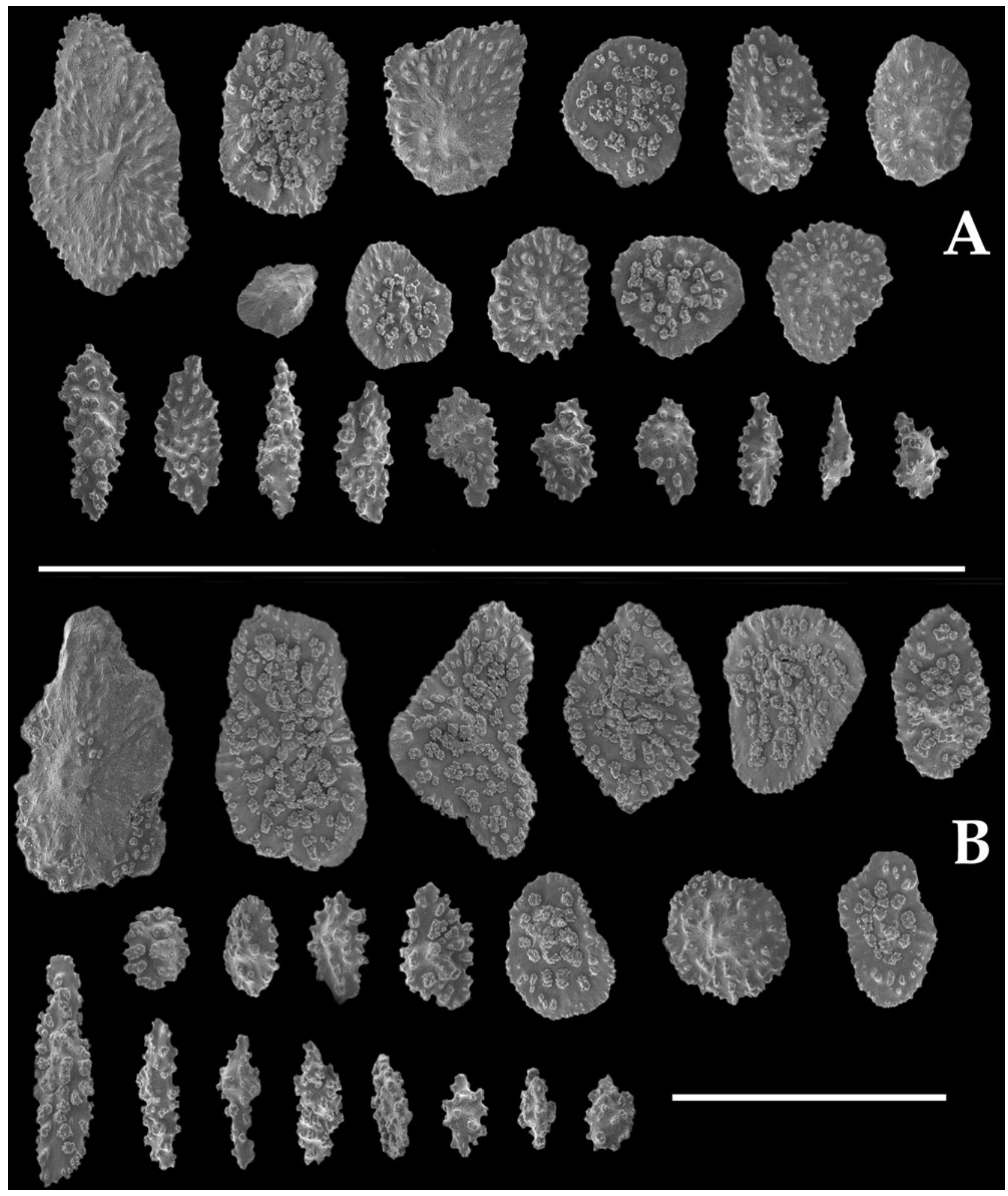

FIG. 6. - Arntzia gracilis (Molander, 1929) comb. nov., colony from EASIZ-II cruise: A, sclerites from the coenechyme between polyps whorls; B, sclerites from the coenechyme at the basal polyp-free portion of the colony. Scale bars: A and B, $0.3 \mathrm{~mm}$.

Primnoidae. In spite of this, Calytrophorinae, and Ainigmaptilinae seem to be the most recognizable subfamilies, the remaining not being consistently differentiated, one from another, according to the criteria given by Wright and Studer (1889), Küken- thal (1924) and the present knowledge of the variability in the family.

Other kinds of research, probably using molecular analyses (DNA sequences, alloenzimes) may be useful and complementary to delimit -in the light of 

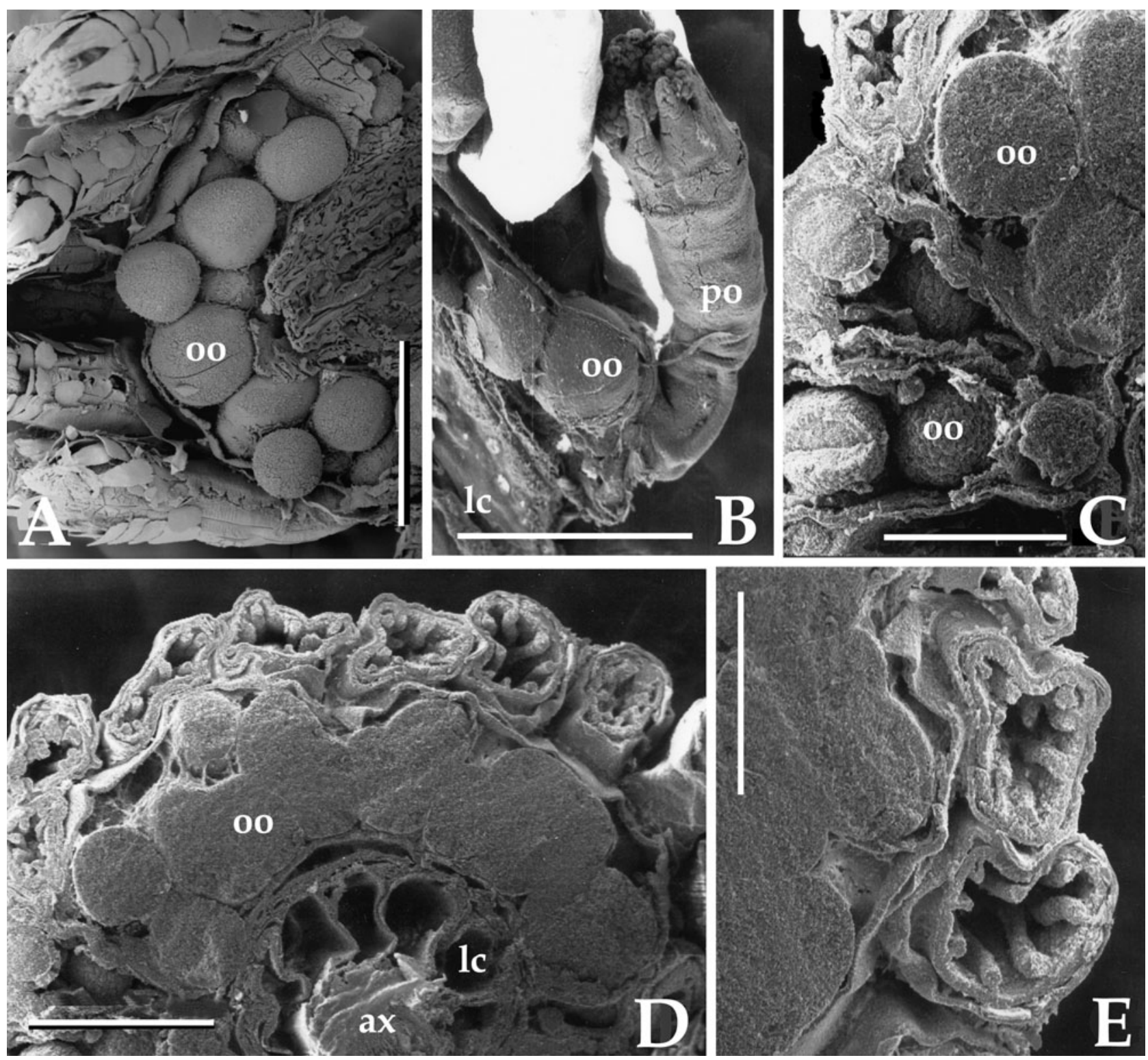

FIG. 7. - Arntzia gracilis (Molander, 1929) comb. nov., colony from EASIZ-II cruise: A, part of a whorl and axial coenenchyme fractured at the common brood-chamber level showing large developing oocytes (oo); B, lateral view of a polyp (po) and the developing oocytes (oo) placed among the cavernous axial coenenchyme, note also the longitudinal canals (lc); $\mathbf{C}$, cross section of a whorl of polyps and common brood-chamber with oocytes (oo), showing the level at which the individuality of the respective coelenteric cavities disappears; $\mathbf{D}$, cross section of a whorl of polyps and common brood-chamber with oocytes (oo), showing the ring of longitudinal canals (lc) and axis (ax); E, detail from D. Scale bars: A and B, $1 \mathrm{~mm} ; \mathrm{C}, 0.4 \mathrm{~mm}$; D, $0.75 \mathrm{~mm}, \mathrm{E}, 0.5 \mathrm{~mm}$.

other criteria- the possible subdivision in subfamilies of the Primnoidae. In this paper we do not try to discuss premature speculations on phylogenetic relationships, which surely could be the goal of other investigations using techniques different to those of traditional taxonomists.

On the other hand, we will demonstrate with certitude that Primnoella gracilis Molander cannot be included in any of the recognized valid genera of the Primnoidae. This fact led us to create a new genus, Arntzia, to accommodate it.
Taxonomic remarks on Arntzia and its closest genera: Primnoella gracilis was described by Molander (1929), however, according to the present re-description and the comments given by Bayer (1996a: 179), this species can not be placed in Primnoella Gray, 1858 (sensu Bayer 1996a) or Convexella Bayer (1996a). Several spicular features present in Arntzia agree with the present knowledge of the genus Ainigmaptilon (= Lycurus Molander) (see Dean, 1926; Molander, 1929; Carlgren, 1943; Bayer, 1950). Nevertheless, noticeable differences 

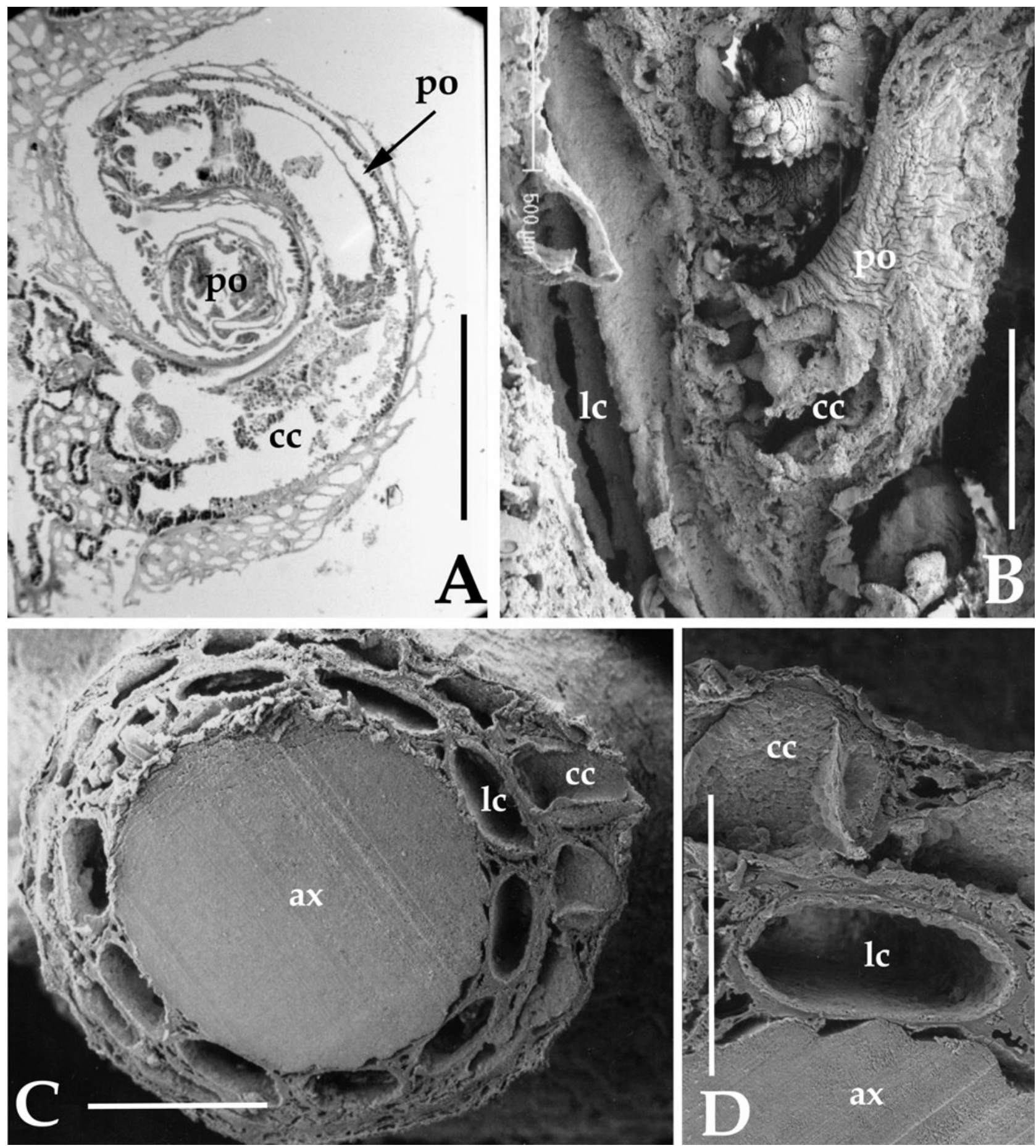

FIG. 8. - Primnoella antarctica Kükenthal from EASIZ-II cruise: A, longitudinal section of a polyp (po1), and transversal section of a contiguous polyp ( po2) throughout the adaxial space of the former, note the coelenteric cavity (cc) and the solenia at the base of polyp; abaxial lacunae are from the decalcified scales; B, the same sample examined by SEM, note the polyp (po), the coelenteric cavity (cc) and the longitudinal canals (lc); $\mathbf{C}$, cross section of the stem at the basal part of a whorl of polyps, showing the general scarce development of the axial coenenchyme, the axis (ax), the ring of oval longitudinal canals (lc), and the basal part of individual coelenteric cavities (cc); D, detail from $\mathrm{C}$, showing the undulate outline of the axis. Scale bars: A and B, $0.4 \mathrm{~mm} ; \mathrm{C}, 0.5 \mathrm{~mm} ; \mathrm{D}, 0.3 \mathrm{~mm}$.

distinguish these two genera as we will discuss below.

Arntzia can be distinguished easily from other primnoid genera which are unbranched or have only a few long flagelliform branches (namely, Primnoel- la, Callozostron Wright, 1885 (see Bayer, 1996a), Ainigmaptilon, Armadillogorgia Bayer (1980), Ophidiogorgia Bayer (1980), and Convexella) by the absence of sclerites at the base of polyps.

In reference to the sclerite rows present on the 

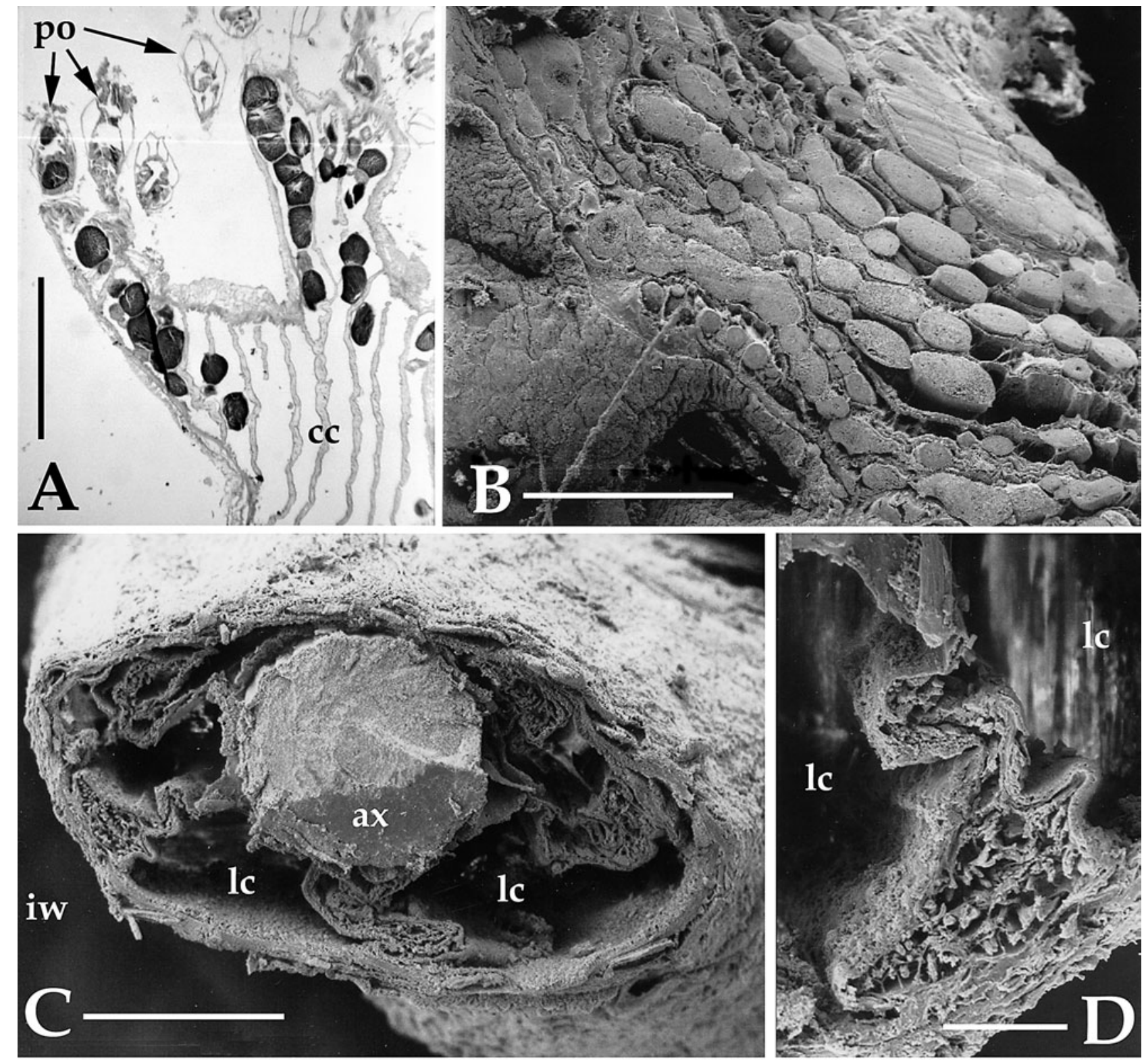

FIG. 9. - Ainigmaptilon antarcticum (Molander) from EASIZ-II cruise. A, longitudinal section of a polyp-leaf, showing the distal part of the polyps (po) and the coelenteric cavities (cc) inside the common polyp-leaf structure, note also the presence of spermatic cysts along the coelenteric cavities of some polyps; $\mathbf{B}$, longitudinal section of a polyp-leaf showing internally the coelenteric cavities of the polyps with numerous spermatic cysts; $\mathbf{C}$, cross section of the stem showing the axis (ax), and the ring of large longitudinal canals (lc) separated by triangular intercanal walls (iw); D, detail from C, showing a triangular intercanal wall delimiting two longitudinal canals (lc). Scale bars: A and B, $1 \mathrm{~mm} ; \mathrm{C}, 0.5 \mathrm{~mm} ; \mathrm{D}, 0.1 \mathrm{~mm}$.

polyps, most or all of the adaxial longitudinal rows of sclerites are absent in Primnoella only, but the arrangement of the remaining rows is quite distinctive. Only two longitudinal rows of sclerites are present on the abaxial side in Primnoella as recently redefined by Bayer (1996a), and the lateral rows are distinct from lateral and adaxial ones (if present). Nevertheless, except for the two adaxial rows, in Arntzia all the body scales are similar in size, the abaxial and lateral scales are identical in appearance.
Polyps are arranged in distinct whorls in all genera above named except for Ainigmaptilon, in which polyps are proximally fused like pennatulacean "polyp-leaves". However, Ainigmaptilon and Arntzia are the only genera in which the distalmost scales are larger than the marginal and submarginal ones, forming a well developed and distinct opercule; in the remaining genera the distalmost scales are indistinguishable from the marginal and/or submarginal scales (Armadillogorgia and Ophidiogorgia), or the distalmost scales, although forming a 
short opercule, are reduced in size and the role of the opercule is assumed by the marginal and/or submarginal scales, which are, at least, similar and often larger in size and ornamentation than the distalmost ones (Callozostron, Primnoella, and Convexella).

There are other similarities in the shape and ornamentation of the opercular and body scales in Ainigmaptilon and Arntzia (see Molander, 1929; Carlgren, 1943; Bayer, 1950), but the arrangement of the groups of polyps and the coenenchymal sclerites are noticeable differences between these two genera. Basal fusion of polyps is sometimes an obscure character in several genera of primnoids with verticillate polyps (see Bayer, 1996a: figs. 8, 9, 12, 15, 24) and could certainly be more frequent than previously reported in the literature. Only Ainigmaptilon shows a more complex polyp arrangement that can be used as a diagnostic character in keys.

Internally, Arntzia is quite different from Ainigmaptilon and Primnoella. In Primnoella the coelenteric cavity ends at the base of the polyp, and contiguous cavities are separate and distinct (Fig. 8 A, B). In addition, a complicated net of solenia connects the different polyps and the distinct ring of oval longitudinal canals (see Fig. 8 C, D). Arntzia and Ainigmaptilon share the partial fusion of the proximal portion of the polyps, these basal parts form a common brood-chamber in Arntzia (see Fig. 7), and a distinct polyp-leaf in Ainigmaptilon, where coelenteric cavities and the results of individual reproductive effort (number of oocytes or spermatic cysts per polyp) are not always distinguishable (Orejas et al. 2002; and Fig. 9 of the present paper). Moreover, some additional differences between Arntzia and Ainigmaptilon should be noted with respect to the aspect of the ring of longitudinal channels. Both genera have large channels, however those of Arntzia are more triangular in section with thin intercanal walls, whereas the canals of Ainigmaptilon are less numerous (4-5) with triangular intercanal walls (see Fig. 9C).

Recently the genus Fannyella has been revised by Bayer (1998). The inclusion of unbranched colonies [see Fannyella nodosa (Molander) in Bayer, 1998: 197], among other characters, enlarges considerably the variability of the genus. Nevertheless, the characteristic ascus-like sclerites of Fannyella are noticeably different to those present in Arntzia.

The fused basal parts of the coelenteric cavities, where the brood-chamber is located run upward through the interior of the axial coenenchyme. This is a unique feature of Arntzia.
The continuation of the coelenteric cavities of the polyps through the common cavernous tissues along the axial coenenchyme or forming distinct polyp leaves, together with the spicular similarities between Arntzia and Ainigmaptilon (=Lycurus) could be the basis for placing both genera in the same subfamily, namely Ainigmaptilinae. However, as indicated above, the unique features of the genus Ainigmaptilon are very different from other primnoids.

General remarks: The families Primnoidae and Plexauridae are the most highly diversified families of gorgonian octocorals (Bayer, 1981). To date, including the new genus described here, 30 primnoid genera are known, of which only a few genera, such as Primnoa Lamouroux, 1812, Callogorgia Gray, 1858, Convexella, and those in the subfamily Calytrophorinae (see Kükenthal, 1915, 1924; Madsen, 1944; Bayer, 1996a) are found in the Northern Hemisphere, the remaining genera being widely distributed in the Southern Hemisphere. With a total of 17 primnoid genera in Antarctic and Subantarctic waters ( 15 of them $-50 \%$ of total- recorded only in this area), the diversity of this family in the Southern Ocean is remarkably high. One of the primary causes put forward as an explanation for the high diversity of certain zoological groups in the waters of the Southern Ocean is the long evolutionary history of the region, which has led to high levels of endemism and speciation (Clarke and Crame, 1992). Accordingly, the fauna observable in the Antarctic today is the outcome of a protracted history of isolation (Lipps and Hickman, 1982). The increasingly frequent sampling of new localities and discoveries relating to the level of spatial heterogeneity (understood as habitat heterogeneity) also lends support to another hypothesis regarding the high levels of diversity in Antarctic waters, namely, that spatial and regional heterogeneity are greater than was originally thought (Lipps and Hickman, 1982). Certain features linked to reproductive strategies support the high level of diversification and endemism enjoyed by the family Primnoidae in the Southern Ocean, as has been observed, for instance, for the fauna off southern Africa (Williams, 1992). Brito et al. (1997) found that the Antarctic gorgonian Thouarella variabilis Wright and Studer had a non-pelagic, lecitotrophic, larval stage that settles near the parent colonies after being released. This reproductive strategy, which appears to be followed by a large number of Antarctic gorgonian species (Gili et al., 
1999), coupled with an extended period of isolation and greater habitat heterogeneity, could account for the high diversity of genera making up the family Primnoidae in the Southern Ocean.

\section{ACKNOWLEDGEMENTS}

Special thanks to Sabine Stöhr and Karin Sindermark (Swedish Museum of Natural History, Stockholm) who provided the loan of the type material of Primnoella gracilis. Additional material of $P$. gracilis was provided by Maria Cristina Gambi (Stazione Zoologica "Anton Dohrn", Naples) from the project "Ecology of the coastal benthic populations of Terra Nova Bay", and Stephen Cairns (Smithsonian Institution, Washington) from the U.S. Antarctic research program.

The authors acknowledge the helpful assistance of the scanning microscope services of the Instituto de Ciencias del Mar de Barcelona (especially $\mathrm{Mr}$ Jose Manuel Fortuño) and the University of Sevilla (Ms Asunción Fernández). They also thank the officers and crew of the Polarstern and the many colleagues for their help on board during the EASIZ and ANDEEP cruises. Special thank are addressed to Mercedes Conradi for her valuable assistance during ANDEEP-I cruise. Support for this work was provided by two CICYT grants (ANT97-1533-E and ANT98-1739-E), Acciones Integradas (HA19980077), Ancciones Especiales (REN2001-4269E/ANT), by $\mathrm{PhD}$ fellowships from DAAD (A/96/13073), and from the European Commission (TMR-CT97-2813). Mr Tony Krupa is thanked for reviewing the final English version.

\section{REFERENCES}

Arntz, W.E. - 1997. Investigación antártica en biología marina: situación actual, proyectos internacionales y perspectivas. Bol. R. Soc. Esp. Hist. Nat. (Sec. Biol.), 93: 13-44.

Arntz, W.E., Brey, T. and V.A. Gallardo. - 1994. Antarctic zoobenthos. Mar. Biol.. Oceanogr. Ann. Rev., 32: 241-303.

Arntz, W.E., Gutt, J. and M. Klages. - 1997. Antarctic marine biodiversity: an overview. In: B. Battaglia, J. Valencia, D.W.H. Walton (eds), Antarctic communities, species, structure and survival, pp 3-14. Cambridge University Press, Cambridge.

Bayer, F.M. - 1950. A new species of the gorgonacean genus Ainigmaptilon Dean (Coelenterata: Octocorallia). J. Washington. Acad. Sci., 40(9):295-298.

Bayer, F.M. - 1980. Armadillogorgia cyathella and Ophidiogorgia paradoxa, two new genera and species of primnoid octocorals (Coelenterata: Anthozoa) from south Georgia and South Orkney Islands. Proc. Biol. Soc. Wash., 93(1): 216-228.

Bayer, F.M. - 1981. Key to the genera of Octocorallia exclusive of Pennatulacea (Coelenterata: Anthozoa), with diagnoses of new taxa. Proc. Biol. Soc. Wash., 94(3): 902-947.

Bayer, F.M. - 1988. Mirostenella articulata, a remarkable new genus and species of primnoid octocoral with uncalcified axial nodes. Proc. Biol. Soc. Wash., 101(2):251-256.

Bayer, F.M. - 1996a. The Antarctic genus Callozostron and its relationship to Primnoella (Octocorallia: Gorgonacea: Primnoidae). Proc. Biol. Soc. Wash., 109(1):150-203.

Bayer, F.M. - 1996b. New primnoid gorgonians (Coelenterata: Octocorallia) from Antarctic waters. Bull. Mar. Sci., 58(2): 511-530.

Bayer, F.M. - 1998. A review of the circumaustral gorgonacean genus Fannyella Gray, 1870 with description of five new species (Coelenterata: Octocorallia: Primnoidae). Senckenberg. biol., 77(2): 161-204.

Bayer, F.M. and J. Stefani. - 1988. Primnoidae (Gorgonacea) de Nouvelle-Calédonie. Bull. Mus. natn. Hist. nat., Paris, (4) 10(A) 3:449-476

Brey, T. and A. Clarke. - 1993. Population dynamics of marine benthic invertebrates in Antarctic and sub-Antarctic environments: are there unique adaptations? Ant. Sci., 5: 253-266.

Brito, T.A.S. - 1993. Taxonomic and ecological studies on Antarctic octocorals of the genus Thouarella (Octocorallia, Primnoidae). Ph.D. Thesis, University of Southampton, England.

Brito, T.A.S., Tyler, P.A. and A. Clarke. - 1997. Reproductive biology of the Antarctic octocoral Thouarella variabilis Wright \& Studer, 1889. In: J.C. den Hartog (ed) Proc. 6th Int. Conf. on Coel. Biol., pp 63-39. Nationaal Natuurhistorisch Museum Leiden.

Carlgren, O. - 1943. Die Alcyonarien-Gattungen Ainigmaptilon und Lycurus. Kungl. Fysiogr. Salskapets. i Lund Forhandl., 13(10): $1-7$.

Clarke, A. and J.A. Crame. - 1989. The origin of the Southern Ocean marine fauna. In: J.A. Crame (ed) Origins and evolution of the Antarctic biota, pp 253-268. The Geological Society London (Geological Society Special Publication 47).

Clarke, A. and J.A. Crame. - 1992. The Southern Ocean benthic fauna and climate change: a historical perspective. Phil. Trans. R. Soc. Lond., B 338: 299-309.

Dean, I. - 1926. Ainigmaptilon haswelli, n. g. et sp.: a new alcyonarian type. J. Linn. Soc. London (Zoology), 36: 337-344.

Gabe, M. - 1968. Technique Histologique. Massou et Cie. Editeurs. Paris.

Gili, J.-M., Arntz, W.E., Filipe P., López, P., Orejas, C., Ros, J. and Teixidó, N. - 1999. The role of benthic suspension feeders in Antarctic communities. In: W. Arntz and J. Gutt (eds) The Expedition ANTARKTIS XV/3 (EASIZ II) of RVPolarstern in 1998, pp 30-83. Berichte Polarforschung, 301, AWI, Bremerhaven.

Johansen, D.A. - 1940. Plant microtechniques. McGraw-Hill. New York \& London.

Kükenthal, W. - 1915. System und Stammesgeschichte der Primnoidae. Zool. Anz., 46 (5): 142-158.

Kükenthal, W. - 1924. Gorgonaria. Das Tierreich,. 1-478.

Lipps, J.H., and C.S. Hickman. - 1982. Origin, age and evolution of Antarctic and deep-sea faunas. In: W.G. Ernst and J.G. Morin (eds) The environment of the deep sea, Rubey volume 11, pp 325-356. Prentice Hall, Englewood Cliffs, New Jersey.

Madsen, F.J. - 1944. Octocorallia. Dan. Ingolf-Exped., 5 (13):1- 65.

Molander, A.R. - 1929. Die Octactiniarien. F. Zool. Res. Swed. Antarc. Exped. 1901-1903, Vol. II, No. 2.

Orejas, C., P.J. López-González, J.-M. Gili, N. Teixidó, J. Gutt, W.E. Arntz.-2002. Distribution and reproductive ecology of the Antarctic octocoral Ainigmaptilon antarcticum in the Weddell Sea. Mar. Ecol. Prog. Ser., 231: 101-114.

Sanders, H.L. - 1968. Marine benthic diversity: a comparative study. Am. Nat., 102: 243-282

Starmans, A., Gutt, J and W.E. Arntz. - 1999. Mega-epibenthic communities in Arctic and Antarctic shelf areas. Mar. Biol., 135: 269-280.

Versluys, J. - 1906. Die Gorgoniden der Siboga Expedition II. Die Primnoidae. Siboga-Exped. Monogr.,13a.: 1-187.

Williams, G.C. - 1992. Biogeography of the octocorallian coelenterate fauna of southern Africa. Biol. J. Linn. Soc., 46: 351-401.

Winston, J.E. - 1992. Systematics and marine conservation. In: N. Eldredge (ed) Systematics, ecology and biodiversity crisis, pp 144-168. Columbia University Press, New York.

Wright, E.P. and T. Studer. - 1889. Report on the Alcyonaria collected by H.M.S. Challenger during the years 1873-1876. Rept. Sci. Res. Challenger, Zool. 31: i-lxxvii + 1-314.

Scient. ed.: P. Abelló 